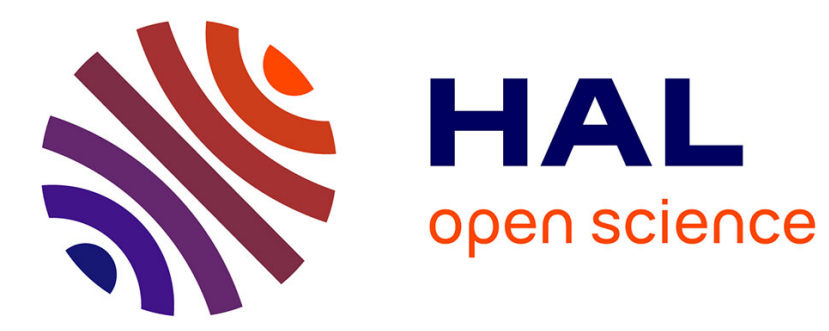

\title{
Evaluating the deployment of alternative species in planted conifer forests as a means of adaptation to climate change-case studies in New Zealand and Scotland
}

\author{
Dean F. Meason, W. L. Mason
}

\section{To cite this version:}

Dean F. Meason, W. L. Mason. Evaluating the deployment of alternative species in planted conifer forests as a means of adaptation to climate change-case studies in New Zealand and Scotland. Annals of Forest Science, 2014, 71 (2), pp.239 - 253. 10.1007/s13595-013-0300-1 . hal-01098411

\section{HAL Id: hal-01098411 \\ https://hal.science/hal-01098411}

Submitted on 24 Dec 2014

HAL is a multi-disciplinary open access archive for the deposit and dissemination of scientific research documents, whether they are published or not. The documents may come from teaching and research institutions in France or abroad, or from public or private research centers.
L'archive ouverte pluridisciplinaire HAL, est destinée au dépôt et à la diffusion de documents scientifiques de niveau recherche, publiés ou non, émanant des établissements d'enseignement et de recherche français ou étrangers, des laboratoires publics ou privés. 


\title{
Evaluating the deployment of alternative species in planted conifer forests as a means of adaptation to climate change-case studies in New Zealand and Scotland
}

\author{
Dean F. Meason • W. L. Mason
}

Received: 14 November 2012 / Accepted: 21 May 2013 / Published online: 21 June 2013

(C) INRA and Springer-Verlag France 2013

\begin{abstract}
- Context A strategy widely proposed for increasing the resilience of forests against the impacts of projected climate change is to increase the number of species planted to spread and reduce the risks from a range of biotic and abiotic hazards.

- Aims We tested this strategy in two case study areas in planted conifer forests in New Zealand and Scotland.

- Methods The performance of the major tree species and an alternative was compared: radiata pine and Eucalyptus fastigata in New Zealand and Sitka spruce and Scots pine in Scotland. The process-based model 3-PG2S was used to simulate the effects of projected climate change at the end of this century, with and without $\mathrm{CO}_{2}$ fertilisation, upon productivity and financial returns. The effects of an abiotic hazard and two biotic hazards were considered.

- Results Under the current climate, the major species outperform alternatives in nearly all circumstances. However, with climate change, their relative performance alters. In New Zealand, planting of E. fastigata becomes more attractive
\end{abstract}

\section{Handling Editor: Douglass Jacobs}

Contribution of the co-authors Dean F. Meason was responsible for the detailed modelling presented in the paper and the analysis of the results of the New Zealand case study.

W.L. Mason was responsible for the analysis of the Scottish case study. Both authors shared in the presentation of the results and the writing of the "Introduction" and the "Discussion" sections.

Electronic supplementary material The online version of this article (doi:10.1007/s13595-013-0300-1) contains supplementary material, which is available to authorized users.

D. F. Meason

Scion, 49 Sala Street, Private Bag 3020, Rotorua 3010,

New Zealand

e-mail: dean.meason@scionresearch.com

W. L. Mason $(\bowtie)$

Forest Research, Northern Research Station, Roslin,

Midlothian EH25 9SY, UK

e-mail: bill.mason@forestry.gsi.gov.uk particularly when various hazards and elevated $\mathrm{CO}_{2}$ concentrations are considered. In Scotland, Scots pine becomes more attractive than Sitka spruce at lower interest rates.

- Conclusions The major plantation species in both countries are well suited to the current climate, but deployment of alternative species and/or breeds can help to adapt these planted forests to the impacts of climate change.

Keywords Climate change $\cdot$ Planted forests $\cdot$ Hazards . Profitability $\cdot$ Species diversification

\section{Introduction}

The last two decades have seen increasing awareness of the potential impacts of projected climate change upon terrestrial ecosystems including forests. In Europe, the mean annual temperature has risen by more than $1.1{ }^{\circ} \mathrm{C}$ compared with conditions before the Industrial Revolution (IPCC 2007). The effect of a warming climate is likely to influence the distribution and growth of tree species and so affect the range of ecosystem services provided by forests (Spittlehouse and Stewart 2003; Lindner et al. 2010; Dunningham et al. 2012). There have been increasing reports of drought-induced dieback and mortality in many parts of the world (Allen et al. 2010). European examples include the dieback of Scots pine (Pinus sylvestris L.) forests in the Southern Alps (Gonthier et al. 2010), increased mortality of several tree species in France after the 2003 heat wave (Landmann and Dreyer 2006), and damage and tree death in Sitka spruce (Picea sitchensis Bong. Carr.) plantations in eastern Scotland (Green et al. 2008). The frequency and intensity of other extreme weather events such as wind storms may also change (Gardiner et al. 2010; Clark 2012), thus risking disruption to timber supplies and a loss of carbon stocks. Increased winter rainfall in Atlantic regions of Europe could increase soil wetness and also contribute to reduced tree stability in annual gales and storms (Ray 2008). 
Decreasing rainfall in eastern areas of Australia and New Zealand may increase drought conditions and the amount of mortality in stands (Battaglia et al. 2009; Dunningham et al. 2012). Climate change may also result in faster growth and higher productivity, particularly in cooler regions where the length of the growing season is predicted to increase without limitations imposed by summer moisture stress (Magnani et al. 2007; Pussinen et al. 2009; Dunningham et al. 2012).

Climate change may also lead to a higher incidence of damage due to biotic pests and pathogens. For example, the worldwide spread of Dothistroma needle blight is thought to be linked to a combination of management practices and climate change favouring the spread of this pathogen (Woods et al. 2005; Watt et al. 2009). The impact of this pathogen in British pine plantations has resulted in a moratorium on the planting of Corsican (Pinus nigra ssp laricio) and lodgepole (Pinus contorta Dougl.) pines (Brown and Webber 2008). Climate warming may favour the spread of damaging pests and pathogens that have been previously limited by cold temperatures. Examples include the major mortality caused by mountain pine beetle (Dendroctonus ponderosae Hopk.) in pine forests in British Columbia (Kurz et al. 2008) and the northwards range expansion of the pine processionary moth (Thaumetopoea pityocampa) in western Europe after increased winter survival due to warming temperatures (Battisti et al. 2005).

One consequence of the growing awareness of climate change and its potential impacts on forests is an increasing uncertainty among forest managers about the most appropriate measures to take to maintain forest health and productivity. While foresters have been aware of the potential impacts of abiotic and biotic risks for many decades (see Schelhaas et al. 2003 on the historic impacts of storms and other disturbances), their decisions have implicitly assumed that such extreme events occurred within a framework of long-term climatic stability and that responses could be based upon accumulated experience (Bolte et al. 2009). However, this assumption is no longer tenable, and the need for effective strategic, tactical, and operational adaptation planning is urgent, not least because the young trees planted or regenerated in contemporary forests will have to cope with a rapidly changing climate over the course of this century. The challenges posed by climate change have led to proposals that future forest management should be based upon principles of 'adaptive management' involving a cycle of planning, implementation, monitoring, and evaluation (Lawrence and Gillett 2011). A strategy of adaptive management of forests is an example of decision making under uncertainty where there is a lack of knowledge both about the degree of climate change that may be experienced in a given region and the way in which a particular forest ecosystem will respond to such pressures (Yousefpour et al. 2012).

A review of stand level adaptation measures reported by 19 European countries found most involved features of an active adaptation strategy such as increasing genetic and species diversity, fostering mixed stands of species considered to be well adapted to future climates, and using a wider range of silvicultural regimes such as continuous cover forestry (Kolstrom et al. 2011). Given that an active adaptation strategy is currently the favoured measure for adapting forests to climate change, an important issue is deciding which measures are most suited to a particular forest or region. For example, at least ten non-native tree species were suggested for planting in north-eastern Germany (Bolte et al. 2009), while over 20 alternative species have been proposed as part of a climate change adaptation strategy in Wales (Anon. 2010). In Australia, a number of alternative species have been identified for possible use in plantation forests in regions where drought risk may be exacerbated by climate change (Battaglia et al. 2009). Thus, there is an emerging view that an appropriate way of spreading the risk of climate change impacts is to increase the species diversity of forests.

This paper presents a pair of case studies examining the effects of an adaptation strategy based upon species diversification on the productivity and financial returns obtained from planted forests in New Zealand and in Scotland. Both countries share similar forest histories in that an extensive period of exploitation and unsustainable management resulted in a loss of native woodland cover followed in the last century by establishment of extensive areas of plantations of fast growing non-native conifers. As a result in 2011, there were $1.8 \mathrm{M}$ ha of planted forests in New Zealand dominated by radiata pine (Pinus radiata D. Don) and $1.1 \mathrm{M}$ ha in Scotland dominated by Sitka spruce. Current silvicultural practices in these forests are outlined in Table 1. The typical structure that results from these regimes is one of regular even-aged stands composed of very few species: thus, $90 \%$ of British forests had three species or less (MCPFE 2007). The situation in New Zealand is similar with almost all the country's commercial timber harvested from even-aged stands of exotic tree species (MAF 2011). We explore how different biotic and abiotic risks consequent upon climate change may affect the outturn from these forests and also consider how the results might influence the operational decision making of forest managers. Our focus is on private forests which comprise nearly all planted forests in New Zealand and $65 \%$ of forests in Scotland.

\section{Materials and methods}

\subsection{Sites}

We chose one case study forest in each country which was located in a region where the main species might be expected 
Table 1 Characteristics of planted forests in New Zealand and Scotland

\begin{tabular}{lll}
\hline Feature & New Zealand & Scotland \\
\hline Planted forest area (M ha) & 1.8 & 1.1 \\
Main species (\%) & Radiata pine (90) & Sitka spruce (52) \\
Important minor species (\%) & Douglas fir (6), Eucalyptus species (1) & Scots pine (13), lodgepole pine (11) \\
Typical rotation length (years) & $25-35$ & $35-50$ \\
Average productivity $\left(\mathrm{m}^{3} \mathrm{ha}^{-1}\right.$ year $\left.^{-1}\right)$ & 27 & 14 \\
Initial spacing (m) & $2.5-3.5$ & 2.0 \\
Pruning & Yes in $50 \%$ stands. 300-450 trees ha ${ }^{-1}$ & No \\
Thinning & $2-3$ times & $2-4$ times $(50 \%$ unthinned because of risk of \\
& & wind damage) \\
Average volume at final felling $\left(\mathrm{m}^{3}\right.$ ha $\left.^{-1}\right)$ & 515 & 400 \\
Amount of genetic gain available over unimproved & $20-40$ & $10-30$ \\
$\quad$ material (\%) & Patch clearfelling and replanting & Patch clearfelling and replanting \\
Main silvicultural system & &
\end{tabular}

Main data sources: 1. New Zealand-MAF (2011); 2. Scotland-Forestry Commission (2012a); Mason and Meredieu (2011). Note that the silvicultural details are for the main species listed unless noted otherwise

to be vulnerable to the effects of climate change and evaluate an alternative commercial forestry species. For New Zealand, the forest selected was Ashley Forest in North Canterbury region of the South Island $\left(43^{\circ} 10^{\prime} 58.9^{\prime \prime} \mathrm{S} 172^{\circ} 34^{\prime} 00.4^{\prime \prime} \mathrm{E}\right)$ with an area of 10,270 ha at elevations between 140 and $865 \mathrm{~m}$ asl. Mean annual rainfall is $800 \mathrm{~mm}$, and mean annual temperature is $10.8{ }^{\circ} \mathrm{C}$. Radiata pine is the preferred choice in this district with the species present in $89 \%$ of the plantation forest area (MAF 2011). The forest is in a region of New Zealand where the combination of warmer temperatures and reduced rainfall are thought likely to increase the risk of severe droughts occurring by the end of the present century (Watt et al. 2008). The Scottish case study was based on Craik Forest in the Scottish Borders region $\left(55^{\circ} 21^{\prime} \mathrm{N}, 3^{\circ} 2^{\prime} \mathrm{W}\right)$, which is an area of 4,729 ha planted since the 1930s on grazing land at elevations between 175 and $425 \mathrm{~m}$ asl and where Sitka spruce represents over $80 \%$ of the tree species present (Mason et al. 2012). Mean annual rainfall is $1,380 \mathrm{~mm}$, and mean annual temperature is $7.1{ }^{\circ} \mathrm{C}$. Craik Forest is typical of the South Scotland region which has the largest standing volume of any supply region in the country and where Sitka spruce comprises over $81 \%$ of the standing volume (Forestry Commission 2012). Although the forest is located in a region where the growth of Sitka spruce is not expected to be limited by median levels of anticipated climate change for much of the century (Ray 2008), recent analysis has suggested that severe moisture deficits could limit the suitability of this species in this forest by the 2050s (Mason et al. 2012).

\subsection{Species}

In both countries, a range of alternative tree species have been proposed for use in adaptation measures. In New Zealand, species considered include various eucalypts (Eucalyptus spp.), coast redwood (Sequoia sempervirens), two cypresses (Cupressus macrocarpa and Cupressus lusitanica), and Australian blackwood (Acacia melanoxylon) (Hay et al. 2005). Most of these species have proved to be rather sensitive to site conditions and microclimate (Nicholas and Watt 2011) with best growth being obtained on fertile free draining soils in sheltered, warm locations. The main exception is Eucalyptus fastigata which, although not present in Ashley Forest, has shown acceptable growth over a range of sites and tolerance of cold, while proving less vulnerable to insect pests and fungal pathogens than other eucalypt species. In Scotland, Mason et al. (2012) examined the potential suitability of 24 alternative tree species for use in Craik Forest under baseline (1961-1990), 2050s, and 2080s future climate scenarios. Among the productive conifer species, Norway spruce (Picea abies Karst.), Scots pine, lodgepole pine, noble fir (Abies procera Rehd.), and Japanese larch (Larix kaempferi Lamb. Carr.) proved suitable under the median climate, but several appeared vulnerable to increased moisture deficits under more extreme climatic projections with only Scots and lodgepole pine remaining suitable. The planting of lodgepole pine is restricted because of the impact of Dothistroma needle blight (Brown and Webber 2008), and therefore, Scots pine should be the safest alternative species for use in the future, although it currently represents only about $1 \%$ of the forest (Mason et al. 2012).

\subsection{Climate change scenarios}

The following data were used to analyse the climate in two time periods, the baseline current climate and one future time period, 2080s, using the United Nations Intergovernmental 
Panel on Climate Change Special Report on Emission Scenario A1B scenario (IPCC 2007; Ray 2008; Mason et al. 2012). Seasonal temperature and rainfall values under current and future periods for both sites are listed in Table S1.

\subsection{Craik}

The baseline climatic data for Craik are for the period 1961 to 1990 (1980 for short). To explore the probability of future climate change in Craik Forest, we used the latest probabilistic climate projections available for the UK (Murphy et al. 2009). These calculations were based on the $25-\mathrm{km}$ grid square surrounding Craik and are projected for the years 2070-2099 (hereafter called the 2080s).

\subsection{Ashley}

The baseline climatic data for Ashley are for the period 1980 to 1999 (1990 for short). New Zealand climate change scenario projections are based on the Canadian Centre for Climate Modelling and Analysis CGCM3 global circulation model (Scinocca et al. 2008). The A1B climate projections were provided by National Institute of Water and Atmospheric research (NIWA) and are based on a $5-\mathrm{km}$ grid square for the years 2080-2099 (hereafter called the 2090st). The NIWA projections provided monthly mean maximum daily temperature, mean minimum daily temperature, and total rainfall. There were no projections available for solar radiation and rain days for this scenario, so current climate values were used. Frost day projections were based on Landcare Research's frost days for the current climate.

\subsection{Forest modelling}

\subsubsection{The 3-PG2S model}

3-PG (physiological processes for predicting growth) is a process-based model developed by Landsberg and Waring (1997). The spatial version of the 3-PG growth model, 3PG2S, was used for this study (Almeida et al. 2010). The process-based model uses subroutines to predict net primary productivity (NPP), transpiration, respiration, and growth. Absorbed photosynthetically active radiation (APAR) is calculated as a function of photosynthetic active radiation and leaf area index. The utilised portion of APAR is established by a series of modifiers with values varying from 0 (total constraint) to 1 (no constraint) (Landsberg and Waring 1997). 3-PG2S simulates the forest's water balance, that is water entering, leaving, and being stored in the system. Water movement in soil discriminates between water in the "root zone" and "non-root zone" of the soil profile. Suboptimal temperatures, high vapour pressure deficits, infertile soils, and soil available water combine to limit photosynthesis and affect growth and allocation of dry mass (Landsberg and Waring 1997). The model has been used to investigate the potential impact of climate change on tree species growth and distribution (Coops and Waring 2010, 2011; Weiskittel et al. 2011). Previous studies were used to obtain the model parameters (details provided in Table S2) for radiata pine (Landsberg and Waring 1997), E. fastigata (Meason et al. 2011), Scots pine (Xenakis et al. 2008), and Sitka spruce (Minnuno et al. 2010). 3-PG2S includes an option to simulate a potential $\mathrm{CO}_{2}$ fertilisation effect with climate change. The "fertilisation effect" is a term that describes the increase in a species NPP that may occur with the increase in atmospheric $\mathrm{CO}_{2}$ concentration enhancing various photosynthesis factors (Ainsworth and Long 2005). As a way to simulate the $\mathrm{CO}_{2}$ fertiliser effect, growth modifiers were introduced for the possible effects of increased atmospheric $\mathrm{CO}_{2}$ to canopy quantum efficiency and canopy conductance to simulate higher leaf intercellular $\mathrm{CO}_{2}$ concentration and higher water use efficiency with higher atmospheric $\mathrm{CO}_{2}$ concentration and lower stomatal conductance (Almeida et al. 2009). When atmospheric $\mathrm{CO}_{2}$ was at $700 \mathrm{ppm}$, canopy quantum efficiency was increased by a factor of 1.4 and canopy conductance by a factor of 0.4 (Sands 2010). The enhancement factors for 3-PG were based on earlier research (Ainsworth and Long 2005; Almeida et al. 2009).

\subsubsection{3-PG2S model input data}

Three sets of spatial data were required to run 3-PG2S; latitude for day length and sun angle, future climatic data, and soil data for soil water balance and fertility subroutines. All datasets were in a grid format, at a 5,000-m resolution. Latitude of each case study area was averaged to the nearest half-degree.

\subsubsection{Climatic data layers}

The monthly climate data surfaces required by the model are mean daily maximum and minimum temperature $\left({ }^{\circ} \mathrm{C}\right)$, rainfall (millimeters), number of rain days (days per month), solar radiation (megajoules per square meter per day), and number of frost days (days per month). Sources of future climatic data for each case study were discussed previously.

\subsubsection{Soil water, depth, and fertility}

Soil texture and potential plant available soil water are required for 3-PG2S soil water balance subroutine. Soil depth affects the level of water storage of a site. Soil fertility information is required to adjust growth rates to the relative fertility of the site. Due to a lack of information, the model's soil fertility index was set to a constant value appropriate for 
the productivity of each species in the case study areas. Sources of texture, depth soil water information for each case-study are discussed below:

\subsubsection{Craik}

Craik's soil data were derived from a 1:10,000 soil survey carried out in the 1970s (personal communication, Bill Rayner, Forest Research) in which soils were allocated to the main soil types and phases distinguished in the British Forestry Commission forest soil classification (Kennedy 2002). The main soil types present are surface water and peaty gleys (approximately $50 \%$ of the forest), brown earths and ironpan soils (25\%) and deep peats (15\%; Mason et al. 2012). For the modelling, we assumed a mean rooting depth of $50 \mathrm{~cm}$ for the gleys and peats and $1 \mathrm{~m}$ for the brown earths and ironpan soils: these categories broadly match those used in more detailed studies (Nicoll et al. 2006).

\subsubsection{Ashley}

Ashley's soil data were from Landcare Research's New Zealand fundamental soil layer textural classification map with a 100-m resolution (Newsome et al. 2008). The main soil types present in the forest are brown and pallic soils. The classification is based on the interpretation of soil surveys from the 1:63,360/1:50,000 scale New Zealand Land Resource Inventory either from reference to analytical results stored in the national soils database or as professional estimates by pedologists acknowledged as authorities in the soils of the region in question (Newsome et al. 2008). Soil textural classes and plant available soil water for each soil unit were based on earlier research (Webb and Wilson 1995). Soil depth information was unavailable; thus, a constant depth of $1 \mathrm{~m}$ was assumed.

\subsubsection{Climate change hazard scenarios}

The hazards we evaluated comprised one abiotic factor (drought) and two biotic factors whose effects should increase with climate change. These were two fungal pathogens in the case of New Zealand and an insect pest and a fungal pathogen in the case of Scotland. Some hazards can increase the probability of occurrence of other hazards and the severity of their impact (e.g. drought and insect outbreak). However, for simplicity the effect of each hazard was simulated separately. Table 2 describes how each hazard was simulated for each abiotic and biotic scenario. As drier conditions are predicted in the regions of Craik and Ashley Forests, the abiotic risk scenario tested the impact of rainfall being half that predicted by future climatology for 5 months of the year and consequent impacts on productivity and wood quality over one rotation (Green et al. 2008;
Stone et al. 2011). For Craik, the drought months were May to September, and for Ashley, November to March.

The biotic factors varied by case study. For Craik, these were the green spruce aphid (Elatobium abietinum) and Dothistroma needle blight. Green spruce aphids feed on the needles of Sitka spruce, resulting in serious defoliation in some years. The severity of green spruce aphid damage is inversely related to winter cold and can result in a loss of at least $10 \%$ of volume at rotation (Straw et al. 2011). Dothistroma needle blight can cause defoliation of the Pinus genus, including Scots pine, and in extreme cases may cause mortality (Brown and Webber 2008). Two pathogens were selected for the Ashley Forest case study based on a review of pests with potential for serious impacts on New Zealand's forest industry (Watt et al. 2011). These were Dothistroma which is already present in New Zealand and a high risk fungal pathogen that has yet to reach New Zealand (Fusarium circinatum, pine pitch canker). Dothistroma currently costs the New Zealand forestry industry $€ 14$ million per annum (Watt et al. 2008), and the North Canterbury region could be optimal for Dothistroma with climate change (Watt et al. 2011). F. circinatum is the causal agent of pine pitch canker, which is characterised by exudation of large amounts of resin in response to an infection and can infect most trees in a stand (Dick 1998). Radiata pine is particularly susceptible to the pathogen, and previous studies have suggested that New Zealand's plantation forests would be particularly vulnerable if it became established (Ganley et al. 2009). Research has indicated that climate change will create conditions in Northern Canterbury that range from suitable to optimal for Fusarium (Watt et al. 2011). For E. fastigata, no pathogen in its home range of South-Eastern Australia or in other countries has yet been identified which has a significant impact on growth. Thus, it was assumed for the scenarios that no pathogen will impact E. fastigata. The risk from fire and wind damage is likely to increase with climate change (Gardiner et al. 2010; Dunningham et al. 2012). Although these risks may have a significant impact, it was assumed that they would have similar impacts for both species equally in each case study. Thus, fire and wind hazards were not included in the hazard scenarios.

\subsubsection{Climate change and hazard simulations}

Stand growth was simulated for each scenario with 3-PG2S using a management regime and rotation length appropriate for each species (details provided in the Table S3). The impact of the abiotic and biotic hazards was incorporated separately for each hazard scenario (Table 2). We then linked the outputs to conventional yield models (Edwards and Christie, 1981 for Scotland) to explore the effects on different product outturns and on the different qualities of 
Table 2 Abiotic and biotic hazards simulated in climate change (CC) risk scenario

\begin{tabular}{|c|c|c|c|}
\hline Scenario & Hazard class & Craik & Ashley \\
\hline CC only & $\mathrm{n} / \mathrm{a}$ & $\mathrm{n} / \mathrm{a}$ & $\mathrm{n} / \mathrm{a}$ \\
\hline $\mathrm{CC}+$ drought & Abiotic & $\begin{array}{l}\downarrow 50 \% \text { summer rainfall. There is an increased } \\
\text { incidence of drought crack in spruce resulting } \\
\text { in no sawlogs suitable for structural use. No } \\
\text { effect on product quality in Scots pine. }\end{array}$ & $\begin{array}{l}\downarrow 50 \% \text { summer rainfall. No changes in } \\
\text { management. }\end{array}$ \\
\hline $\mathrm{CC}+$ Dothistroma & Biotic & $\begin{array}{l}\text { First two thinnings are } 20 \% \text { heavier than } \\
\text { standard to reduce disease impact. Later } \\
\text { thinnings and final volume reduced by } \\
20 \% \text { to allow for impact of needle loss. }\end{array}$ & $\begin{array}{l}\text { Severe outbreak causes widespread defoliation } \\
\text { and reduces growth. Harvest volume } \\
\text { reduced by } 10 \% \text {. No changes in management }\end{array}$ \\
\hline $\mathrm{CC}+$ Fusarium circinatum & Biotic & $\mathrm{n} / \mathrm{a}$ & $\begin{array}{l}\text { Severe outbreak causes widespread resin bleeding } \\
\text { throughout the stem. Harvest volume not } \\
\text { impacted. However, the highly valuable P1 } \\
\text { timber grade cannot be recovered and all log } \\
\text { grades are reduced by one grade. No changes } \\
\text { in management }\end{array}$ \\
\hline $\mathrm{CC}+$ Elatobium abietinum & Biotic & $\begin{array}{l}\text { Assumed } 5 \% \text { loss in increment until year } 30 \\
\text { and } 10 \% \text { thereafter (Straw et al. 2011) }\end{array}$ & $\mathrm{n} / \mathrm{a}$ \\
\hline
\end{tabular}

timber produced (details provided in Tables S4 and S5). Thus, in the abiotic drought scenario, we assumed that one consequence for Sitka spruce would be that the incidence of drought crack was such that no timber suitable for sawlogs was produced. For each scenario, an average recoverable volume from thinnings and at final harvest for each forest was used to calculate net present value (NPV) financial analysis. Costs and revenues were based on latest standard data for operations in each country and calculated NPV's reported in Euros (details provided in Tables S4 and S5). No subsidies were included in the revenue streams. Interest rates used in Scotland were varied between 1 and $5 \%$, spanning the historic rates of return on planted forests in Britain (Richards 2003). The equivalent rates used in New Zealand ranged from 5 to $10 \%$ (Manley 2012). Then, the NPV of each scenario was compared to evaluate the impact of climate change and hazards on species profitability. While a number of other technical approaches are available to evaluate the returns on investments in forest plantations, discussions with managers of private forests in both New Zealand and Scotland showed that NPV was the main method employed (unpublished data).

The $\mathrm{CO}_{2}$ fertiliser effect with increasing atmospheric $\mathrm{CO}_{2}$ concentration may increase net primary productivity. However, the experimental evidence that the $\mathrm{CO}_{2}$ fertiliser effect increases NPP long term is uncertain due to a number of physiological and environmental factors (Karnosky 2003). Thus, two values were produced for each scenario, with and without the $\mathrm{CO}_{2}$ fertiliser effect. The low end of future productivity was provided by simulations without a $\mathrm{CO}_{2}$ fertilisation effect (using current ambient atmospheric $\mathrm{CO}_{2}$ ). The results from the model scenarios were compared to simulated productivity using current climate data.

\subsubsection{Sensitivity analysis}

Two sensitivity analyses were performed by varying model inputs and NPV financial inputs by \pm 10 and $\pm 40 \%$. The first analysis identified the effect of each model input parameter on the stem volume outputs of each species under the future climate scenario assuming a $\mathrm{CO}_{2}$ fertiliser effect. Model inputs tested were mean daily maximum temperature, mean daily minimum temperature, rainfall, solar radiation, frost days, and soil fertility. The analysis under a future climate without a $\mathrm{CO}_{2}$ fertiliser effect produced similar levels of sensitivity; therefore, these results were not considered further. The second sensitivity analysis determined the effect of changing revenues and costs on NPV for the climate change only scenario. This scenario was selected to test the relative impact of revenues and costs without the additional impact of the hazards. One interest rate was used for this analysis, $3 \%$ for Craik and $7 \%$ for Ashley. All changes to revenues and costs were applied uniformly (i.e. no attempt was made to vary the difference in revenue between different products).

\section{Results}

Projected climate change increased mean annual temperature for Craik by $47 \%\left(2.9^{\circ} \mathrm{C}\right)$ and at Ashley by $27 \%\left(2.9^{\circ} \mathrm{C}\right)$. Annual rainfall increased for Craik by $1 \%(12 \mathrm{~mm})$, while at Ashley, rainfall decreased by $27 \%(216 \mathrm{~mm})$. Total number of frost days per year decreased at Craik by $51 \%$ (52 days) and Ashley decreased by $19 \%$ (14 days). Without the $\mathrm{CO}_{2}$ fertiliser effect, recoverable volume at final felling under climate change increased for Scots pine and E. fastigata 
(Table 3). Conversely, recoverable volume for Sitka spruce and radiata pine showed a small decrease under climate change (Table 3). When a $\mathrm{CO}_{2}$ fertiliser effect was assumed along with the future climate, recoverable volumes increased for all four species (Table 3). The drought risk scenario combined with climate change decreased volume for all four species, unless a $\mathrm{CO}_{2}$ fertiliser effect was assumed (Table 3 ). The biotic risk scenarios with climate change decreased volume of the host tree species to varying degrees (Table 3).

For Craik Forest under climate change and no $\mathrm{CO}_{2}$ fertilisation, the species with the highest NPV varied by risk scenario. Sitka spruce provided the highest NPV under the current climate (Fig 1a). With climate change only, the NPV from Sitka spruce decreased and that from Scots pine increased with the latter having a higher NPV at the lower interest rates (Fig 1a). When a $\mathrm{CO}_{2}$ fertiliser effect was assumed with climate change, the net increase in productivity for Scots pine was higher than for Sitka spruce (Table 3). This resulted in a higher NPV in 2080 for Scots pine when interest rates were between 0 and $3 \%$ (Fig. 1b). When the drought scenario was considered, there was little difference in NPV between both species under current climate conditions (Fig 1c). Combined with climate change, both species 2080 NPV's were similar, except that Scots pine was higher at the lowest interest rates (Fig. 1c). When the $\mathrm{CO}_{2}$ fertiliser effect was assumed for the drought scenario, future NPVs were greater than current climate NPVs (Fig. 1d). Scots pine's $2080 \mathrm{NPV}$ was still greater than Sitka spruce's 2080 NPV when interest rates were less than $2 \%$; however, the difference in NPV was smaller than in Fig. 1a. Dothistroma decreased Scots pine recoverable volume and NPV under current and future climates (Fig. 1e). When the $\mathrm{CO}_{2}$ fertiliser effect was assumed, Scots pine had a larger 2080 NPV than Sitka spruce at interest rates less than $2 \%$ (Fig 1f), while at higher interest rates, both species had a similar rate of return (Fig. 1f). Elatobium decreased Sitka spruce's NPVs for current and future climates (Fig. 1g, h). Without a $\mathrm{CO}_{2}$ fertiliser effect, Scots pine only had a larger return than Sitka spruce at interest rates less than $2 \%$ in 2080 (Fig 1g). With a $\mathrm{CO}_{2}$ fertiliser effect, Scots pine 2080 NPV was larger than Sitka at interest rates less than $3 \%$ (Fig 1h).

For Ashley Forest, radiata pine NPV was constantly higher than E. fastigata NPV under current climate conditions (Fig 2a). Under current conditions, volume at harvest for radiata pine was double E. fastigata (Table 3), as well as having a shorter rotation. With climate change, both species' productivity increased with warmer temperatures. However, E. fastigata responded more than radiata pine with large increases in volume without (50\%) and with (180\%) the $\mathrm{CO}_{2}$ fertiliser effect (Table 3). This reduced the difference in recoverable volume at harvest between the species (Table 3), so that E. fastigata provided at least as high a NPV as radiata pine in 2090 without and with the $\mathrm{CO}_{2}$ fertiliser effect (Fig. 2a, b). The drought risk scenario reduced the recoverable volume from radiata pine under current climate and climate change (Table 3). This scenario reduced radiata pine's NPV (Fig. 2c, 2d). Drought had little impact on $E$. fastigata's growth under current climate or with climate change (Table 3). Thus, E. fastigata's NPV was higher than radiata pine in 2090 (Fig. 2c, d).

The Dothistroma risk scenario at Ashley Forest reduced recoverable volume of radiata pine under current climate (Table 3); however, radiata pine NPV was still higher than E. fastigata (Fig. 2e, f). Dothistroma plus climate change caused a large reduction in recoverable volume with radiata pine (Table 3 ). This reduction meant that E. fastigata under this risk scenario had a larger profit margin for most rates of return without (Fig. 2e) and with (Fig. 2f) the $\mathrm{CO}_{2}$ effect. The Fusarium risk scenario had the biggest impact on radiata pine NPV. Under current climate conditions, the downgrade in log grades caused radiata pine NPV to be less than E. fastigata at interest rates between 5 and $7 \%$ (Fig. 2g, h). The potential impact of Fusarium was clearly demonstrated when it was combined with climate change. The warmer climate greatly benefited $E$. fastigata productivity with high recoverable

Table 3 Recoverable volume (cubic meters per hectare) at final harvest predicted by 3-PG2S for each climate change and risk combination

\begin{tabular}{|c|c|c|c|c|c|c|c|c|}
\hline \multirow[t]{2}{*}{ Scenario } & \multicolumn{2}{|l|}{ Sitka spruce } & \multicolumn{2}{|l|}{ Scots pine } & \multicolumn{2}{|l|}{ Radiata pine } & \multicolumn{2}{|l|}{ E. fastigata } \\
\hline & No $\mathrm{CO}_{2}$ effect & $\mathrm{CO}_{2}$ effect & No $\mathrm{CO}_{2}$ effect & $\mathrm{CO}_{2}$ effect & No $\mathrm{CO}_{2}$ effect & $\mathrm{CO}_{2}$ effect & No $\mathrm{CO}_{2}$ effect & $\mathrm{CO}_{2}$ effect \\
\hline Current & 444 & $\mathrm{n} / \mathrm{a}$ & 239 & $\mathrm{n} / \mathrm{a}$ & 348 & $\mathrm{n} / \mathrm{a}$ & 156 & $\mathrm{n} / \mathrm{a}$ \\
\hline Current + drought & 373 & $\mathrm{n} / \mathrm{a}$ & 233 & $\mathrm{n} / \mathrm{a}$ & 289 & $\mathrm{n} / \mathrm{a}$ & 160 & $\mathrm{n} / \mathrm{a}$ \\
\hline Climate change (CC) & 388 & 652 & 351 & 662 & 330 & 692 & 236 & 450 \\
\hline $\mathrm{CC}+$ drought & 337 & 580 & 327 & 610 & 283 & 554 & 240 & 459 \\
\hline $\mathrm{CC}+$ Dothistroma & $\mathrm{n} / \mathrm{a}$ & $\mathrm{n} / \mathrm{a}$ & 281 & 606 & 297 & 623 & $\mathrm{n} / \mathrm{a}$ & $\mathrm{n} / \mathrm{a}$ \\
\hline $\mathrm{CC}+$ Fusarium circinatum & $\mathrm{n} / \mathrm{a}$ & $\mathrm{n} / \mathrm{a}$ & $\mathrm{n} / \mathrm{a}$ & $\mathrm{n} / \mathrm{a}$ & 330 & 692 & $\mathrm{n} / \mathrm{a}$ & $\mathrm{n} / \mathrm{a}$ \\
\hline $\mathrm{CC}+$ Elatobium abietinum & 348 & 587 & $\mathrm{n} / \mathrm{a}$ & $\mathrm{n} / \mathrm{a}$ & $\mathrm{n} / \mathrm{a}$ & $\mathrm{n} / \mathrm{a}$ & $\mathrm{n} / \mathrm{a}$ & $\mathrm{n} / \mathrm{a}$ \\
\hline
\end{tabular}


Fig. 1 Net present value (euros per hectare) for Sitka spruce and Scots pine for current and future climate and risk scenarios. Risk assessment scenarios; climate change only (a, b), climate change + drought (c, d), climate change+ Dothistroma (e, f), and climate change + E. abietinum $(\mathbf{g}, \mathbf{h})$. For each risk assessment, a scenario without the $\mathrm{CO}_{2}$ fertiliser effect and a scenario with the $\mathrm{CO}_{2}$ fertiliser effect were simulated

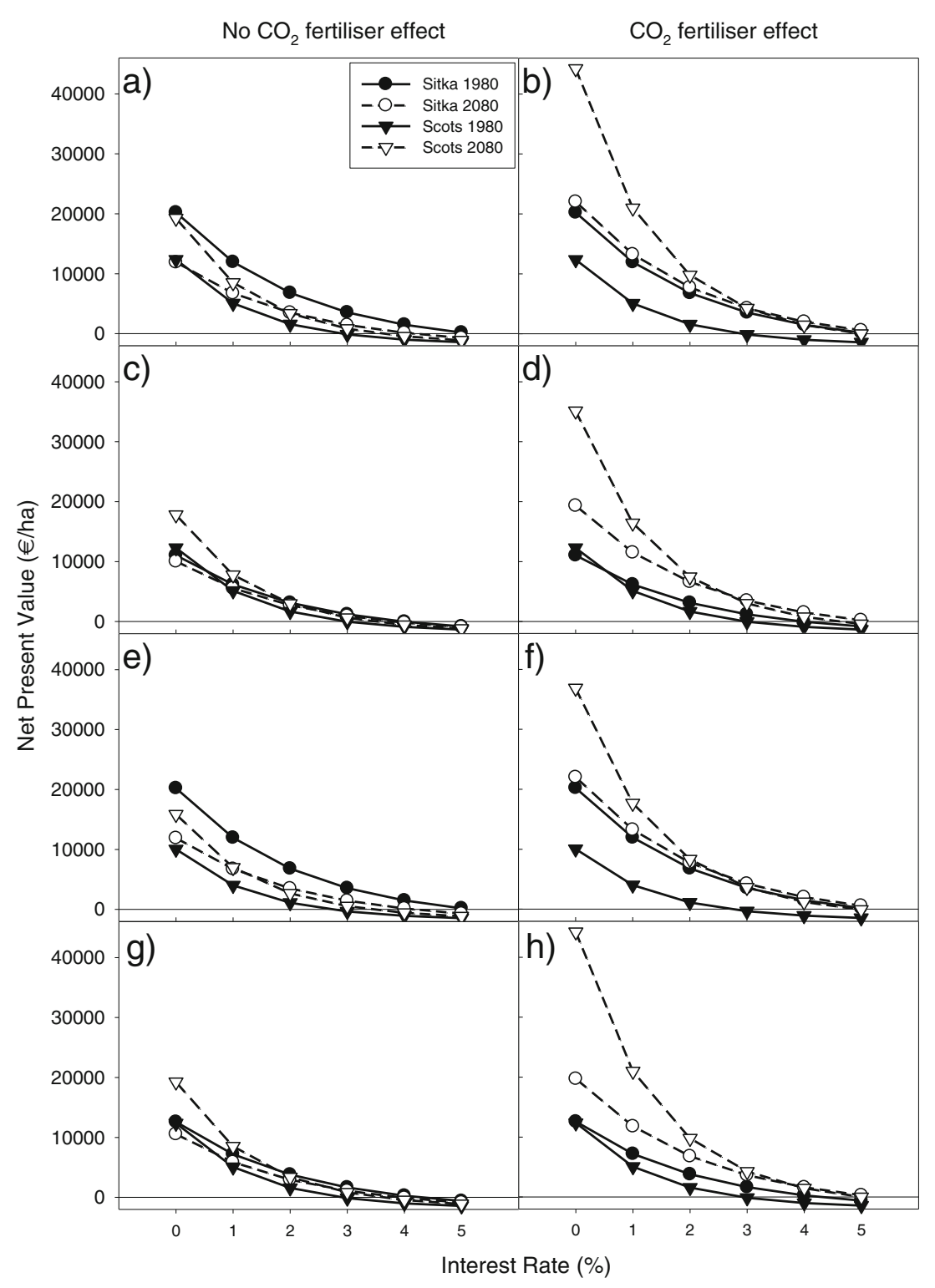

volumes in 2090 (Table 3). As this pathogen did not downgrade E. fastigata log grades, its NPV was high without (Fig. 2g) and with (Fig. 2h) the $\mathrm{CO}_{2}$ fertiliser effect. Even with the hypothesised increase in productivity with higher atmospheric $\mathrm{CO} 2$, the log downgrades for radiata pine meant that its NPV was at least $60 \%$ smaller than E. fastigata between 5 and $8 \%$ interest rate (Fig. 2h).

Sensitivity analysis suggested that Scots pine productivity was more responsive to the 3-PGS2 input variables than Sitka spruce (Fig. 3a, b). Both species were most sensitive to mean daily maximum temperature and daily solar radiation. In contrast, radiata pine was more affected by input variables than E. fastigata (Fig. 3c, d), being most responsive to mean daily maximum temperature (Fig. 3c). E. fastigata was affected by mean daily maximum temperature and daily solar radiation, and soil fertility (Fig. 3d).
Sensitivity analysis of NPV at an interest rate of $3 \%$ for Craik and $7 \%$ for Ashley found changes in stumpage price had a larger impact than the costs (Fig. 4). In the current climate, Sitka spruce and radiata pine always produced the highest NPVs. At Craik Forest in 2080, Sitka spruce tended to be more profitable than Scots pine except where revenues were reduced by $40 \%$. At Ashley Forest in 2090, radiata pine stumpage would need to increase by $14 \%$ (Fig. 4c) or E. fastigata costs will need to increase by $21 \%$ (Fig. $4 \mathrm{~d}$ ) for radiata pine to be the more profitable species.

\section{Discussion}

The results show that, in each case study, the major plantation species (i.e. Sitka spruce or radiata pine) outperformed a potential alternative species (Scots pine or E. fastigata) 
Fig. 2 Net present value (euros per hectare) for radiata pine and E. fastigata for current and future climate and risk scenarios. The future climate scenario assumes no $\mathrm{CO}_{2}$ fertiliser effect. Risk scenarios: climate change only (a, b), climate change + drought $(\mathbf{c}, \mathbf{d})$, climate change + Dothistroma (e, f), and climate change $+F$. circinatum $(\mathbf{g}, \mathbf{h})$. For each risk assessment, a scenario without the $\mathrm{CO}_{2}$ fertiliser effect and a scenario with the $\mathrm{CO}_{2}$ fertiliser effect were simulated

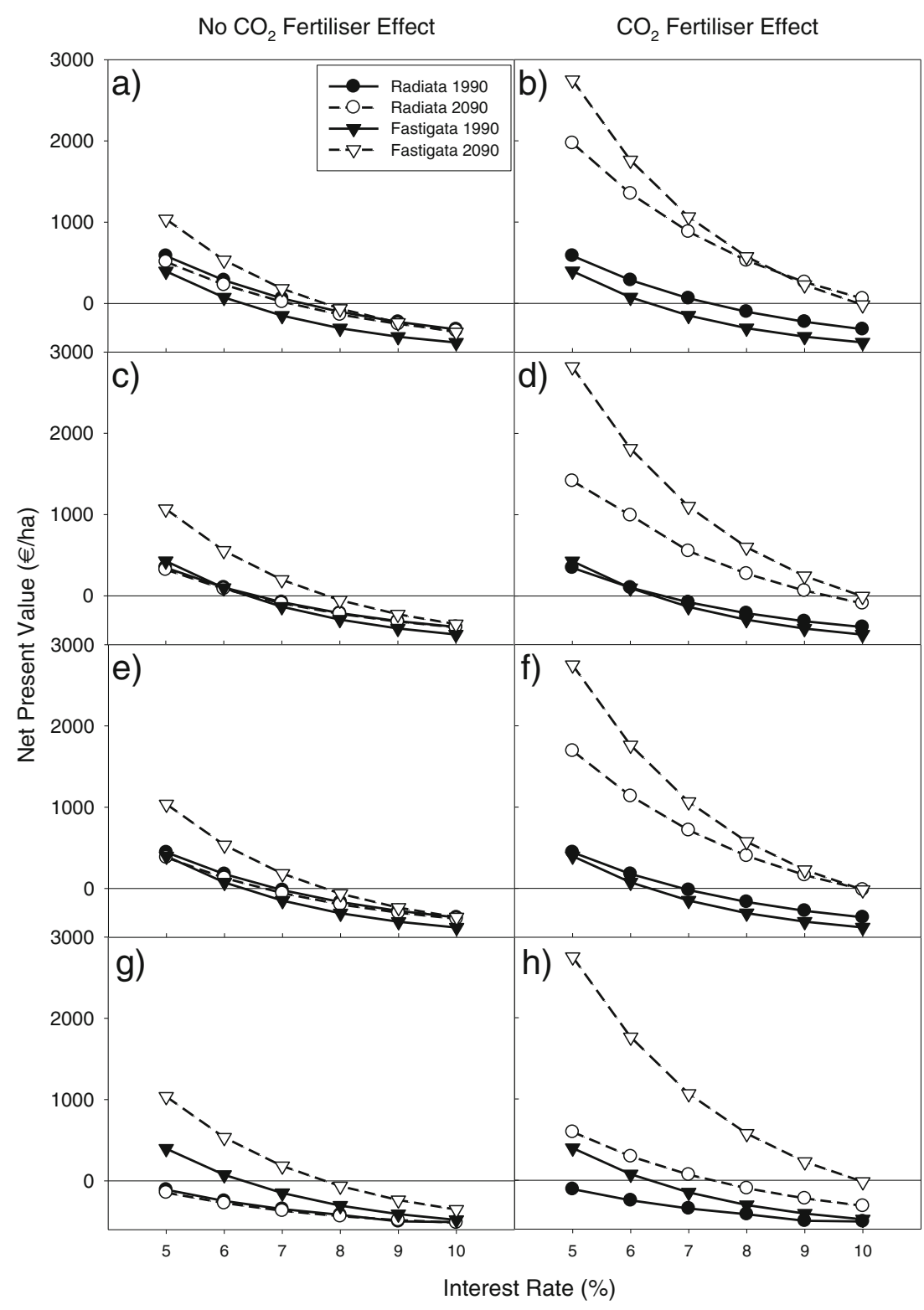

under the current climate conditions in terms of both productivity and NPV (Table 3; Figs. 1 and 2). This finding holds even if the impacts of abiotic or biotic hazards were incorporated, with the exception of $F$. circinatum effects on radiata pine (Fig. 2f). However, when projected climate change was incorporated into the analysis, model simulations suggested that, in each country, there would be a decline in recoverable volume at final harvest for the major productive species of 7 to $13 \%$ (Table 3 ) by the end of this century. In contrast, there was projected to be a 15 to $30 \%$ increase in productivity for the potential alternative species. The practical effect is to alter the relative profitability of the alternative species compared to the major species (Figs. 1a and 2a). The magnitude of the change depends upon the interest rate used in the evaluation, since at higher interest rates the longer rotations involved with the alternative species (e.g. Scots pine) may prove less attractive (Fig. 1a). The sensitivity of Sitka spruce to projected climate change in 2080 indicated by the simulations agrees with an earlier evaluation indicating that Sitka spruce would be vulnerable to the severe moisture stress projected under more extreme conditions (Mason et al. 2012). Our study did not simulate the effects of planting breeds of a species resistant to the biotic hazards, for example Dothistroma-resistant strains of radiata pine (Burdon, 2001). The aim of this study was to indicate the potential impact of a severe pest or pathogen outbreak on susceptible plantation forests. Although resistant trees would lessen the impact of the biotic hazards, the recoverable volume from an outbreak is likely to be less than the climate change only scenario. Higher temperatures had the biggest impact on the species with climate change, not biotic hazards. These hazards increased the impact of 
Fig. 3 3-PGS2 model sensitivity analysis of variation in stand volume (cubic meters per hectare) with changes in input variables; soil fertility (black circle), frost days per month (white circle), monthly rainfall (black down-pointing triangle), average daily solar radiation (white up-pointing triangle), monthly mean daily maximum temperature (black square), and monthly mean daily minimum temperature (white square), for Sitka spruce (a), Scots pine (b), radiata pine (c), and E. fastigata (d)

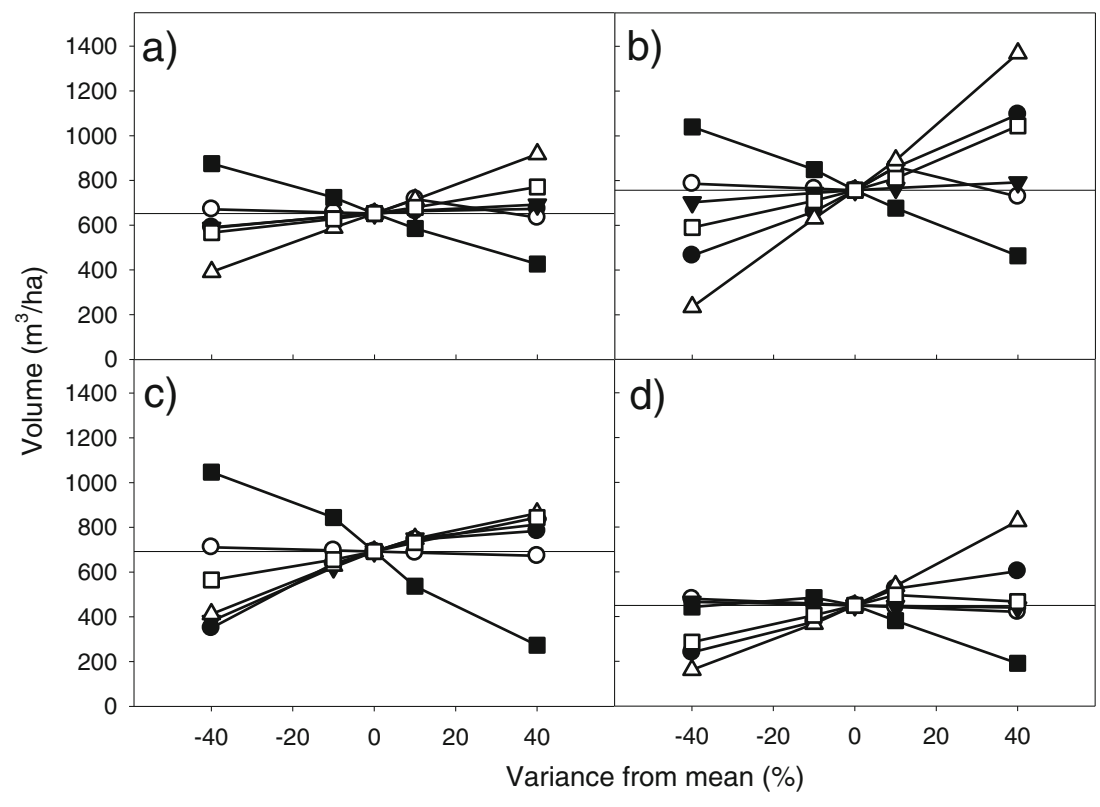

higher temperatures on future productivity and NPV rather than changing the relative profitability of species.

The revenues from timber and the costs of forestry operations can be quite uncertain 10 years into the future, let alone over the timelines used in this study. Due to these uncertainties, current stumpage prices at harvest and costs for forest operations were used. The profitability of a species under a climate change risk scenario can be highly sensitive to the revenue and cost assumptions used. In addition, there will always be uncertainty involved in predicting tree species productivity under a future climate as the precise changes in climatic parameters are unknown. Further, the effect of these changes on a species' physiology is imperfectly understood which affects in turn the assumptions on tree growth embodied in 3-PG. Thus, the predicted species volumes and NPVs are subject to a degree of uncertainty. We believe the outcomes presented in this study represent the productivity of each species under a future climate based on the best current understanding of climate change and its impacts on tree physiology. Within these limits, the financial sensitivity analysis indicated that for radiata pine to be more profitable than E. fastigata under climate change, radiata pine revenue would have to increase and/or costs decrease by large margins. By contrast, the Sitka spruce and Scots pine results are quite similar under future climate change scenarios, suggesting that careful comparison of anticipated revenues and costs is essential for an informed species choice.
Fig. 4 Financial sensitivity analysis of alteration in net present value (euros per hectare) to changes in revenues and costs at Craik forest (a and b, respectively) at $3 \%$ interest rate and Ashley forest (c and $\mathbf{d}$, respectively) at $7 \%$ interest rate by species; Sitka spruce (closed circles), and Scots pine (open triangles), radiata pine (closed squares), and E. fastigata (open diamonds); and by risk scenario; current climate conditions (solid line), climate change (dashed line), and climate change with $\mathrm{CO}_{2}$ fertiliser effect (dotted line)

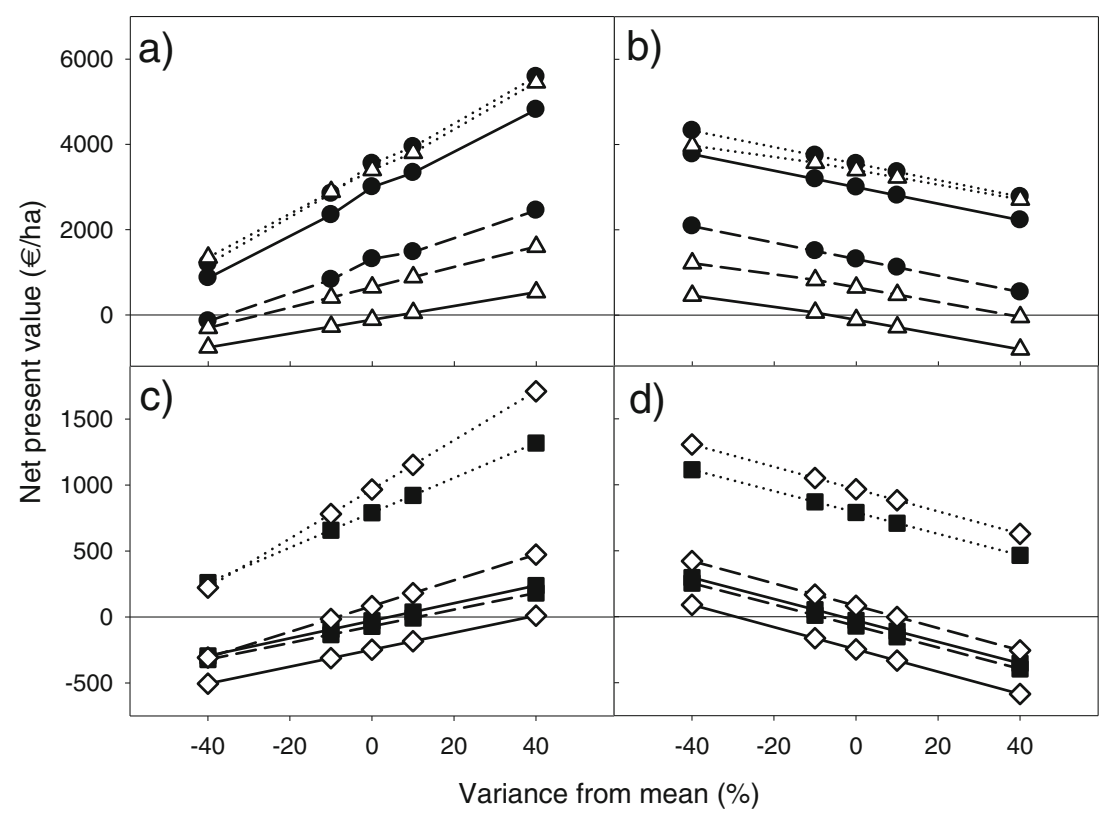


The use of NPV as a criterion for making comparison between species performance under future climate scenarios may be questioned, given recent papers that have considered more sophisticated approaches to incorporating risk and uncertainty in adaptive forest management (Hildebrandt and Knoke 2010; Yousefpour et al. 2012). However, our discussions with private sector forest managers in both countries showed NPV to be widely used in assessment of silvicultural options such as deployment of alternative species. Risks were allowed for, if at all, by using conservative values for the returns (e.g. downgrading the amount of sawlog outturn to be achieved at final harvest) or by varying the interest rate used when comparing returns to be obtained from different species. Manley (2012) indicated that similar approaches are used by valuers in assessing planted forests in New Zealand. We therefore consider that the use of NPV is justified as a criterion for species selection since it reflects the operational decision environment within commercial forestry. The tendency for such decisions to embrace a time frame of no more than one or two decades (Hoogstra and Heiner 2009; Lawrence and Gillett 2011) is a potential issue when trying to develop strategies of adapting forests to climate change impacts half a century or more away.

The sensitivity of 3-PG to individual parameters and model feedbacks has been well researched in other studies (Esprey et al. 2004, Xenakis et al. 2008, Song et al. 2012). As only one model was used in this study, the same degree of sensitivity of the parameters was applied equally to all species. The sensitivity of the model's outputs to input parameters did vary by species (Fig. 3). All species were quite sensitive to solar radiation; however, since neither the UK or New Zealand climate change models had simulated solar radiation under the future climate scenarios, current solar radiation amounts were used. All species were sensitive to daily maximum temperatures as it impacts vapour pressure deficit. This indicates that a temperature increase above a species optimum temperature may lead to a significant decline in productivity. The sensitivity analysis showed that if future daily maximum temperatures were over- or under-estimated by $20 \%$ or more, then this will have a large impact on harvest volume for all species. A surprising result was that the model outputs were not particularly sensitive to soil fertility probably due to the scant soil information, including fertility, for these sites. As uniform soil input values were used for these forests due to a lack of information, the sensitivity of model outputs to these variables was lessened.

At both sites, a rise in temperature was the major driver of this projected increase in productivity of the alternative species Scots pine and E. fastigata. At Craik, the projected change in temperature would affect Sitka spruce adversely since the stomata of this species are sensitive to increases in vapour pressure deficit, resulting in reduced carbon uptake at higher temperatures (Jarvis et al. 2009). The small increase in temperature did not increase Sitka spruce productivity, but Scots pine productivity did increase. Scots pine benefited more from this increase as the mean annual temperature at Craik became closer to the species' optimal growing temperature. This combined with a lesser sensitivity to an increase in vapour pressure deficit meant that Scots pine productivity strongly increased while Sitka spruce did not. At Ashley, there was a decrease in rainfall with the A1B scenario. For E. fastigata, this decrease was more than offset by the increase in temperature. Eucalyptus species are in general well adapted to drier conditions with less soil water and higher vapour pressure deficit. Thus, E. fastigata productivity greatly benefited from climate change. The rise in temperature at Ashley was closer to radiata pine's optimal growth temperature of $20{ }^{\circ} \mathrm{C}$. However, the decrease in rainfall and soil water was enough to cause increased water stress during the summer months, which reduced photosynthesis and productivity. The impact of increasing temperatures also meant a large decrease in the number of frost days. Both Craik and Ashley are frost-prone sites in the present climate. Thus, the reduction in occurrence of frost resulted in an increase in the total number of growing days and hence increased productivity. However, as the sensitivity analysis showed, all species were more sensitive to maximum mean daily temperature.

The $\mathrm{CO}_{2}$ fertiliser effect increased productivity and NPV for all species. The hypothesis supporting this effect is that higher ambient $\mathrm{CO}_{2}$ concentrations with climate change will increase the concentration of leaf intercellular $\mathrm{CO}_{2}$. With more $\mathrm{CO}_{2}$ within the leaf, maximum quantum use efficiency will increase, less stomatal conductance will be needed for photosynthesis, and water use efficiency will increase. The model uses a constant factor for the maximum photosynthetic conversion of photosynthetically active radiation into gross primary productivity. The appropriateness of using the same constant for all species has been debated (Lansberg and Waring 1997; Waring and McDowell 2002; Seidl et al. 2005); however, the model has performed well for a wide variety of species with this constant under current climate conditions. As the model was able to accurately simulate productivity for all for species under the present climate, it is reasonable to assume that this constant will be valid under future climates. When revenues and costs were constant, future NPVs were primarily influenced by future climatologies, and the effects of the hazards. The $\mathrm{CO}_{2}$ fertiliser effect only exaggerated the differences between species, it did not change which species had the highest NPV for each climate change risk scenario. There is considerable debate on the magnitude of the $\mathrm{CO}_{2}$ fertiliser effect, or even if it will even increase net primary production of trees in the long term (Karnosky 2003; Norby et al. 2010; Abrams 2011 Booth 2012). Despite this uncertainty, it seems reasonable to 
assume that productivity under climate change will probably fall somewhere between the values presented when $\mathrm{CO}_{2}$ effect was not included (lower bound) and when it was included (upper bound) in the simulations.

The preceding sections show that the impact of projected climate change raises questions about the long-term viability of the current reliance in both countries upon a single species to supply timber from an extensive plantation resource. In other words, there appear to be increasing biological risks involved in maintaining current silvicultural regimes and practices into an uncertain future, particularly on sites where the projected combination of increasing temperatures and static or declining rainfall exposes the major plantation species to increased moisture stress. However, our analysis suggests that the silvicultural responses to this uncertainty might vary between the two countries. Thus, in the New Zealand case study, E. fastigata offers an alternative which, provided the species remains free from pests and pathogens, seems as or more financially attractive than radiata pine at prevailing interest rates under most of the scenarios incorporating climate change (Fig. 2). This is one of the important preconditions for encouraging managers of plantation forests to consider a change of species (Pinkard et al. 2010). E. fastigata is able to produce high-quality sawn timber with a rotation of less than 35 years (Jones et al. 2010), which was the management scenario used in this study. End-use products of E. fastigata timber include high-valued furniture and joinery (Davis-Colley and Nicholas 2008). The species also has desirable properties for pulp and paper; however, this was not considered in this study. If a new, unknown pathogen or pest impacted $E$. fastigata productivity in the future, the species would still remain more profitable in 2090 than radiata pine in the Dothistroma and Fusarium hazard scenarios until volume growth of E. fastigata was reduced by 20 and $50 \%$, respectively.

By contrast, in the Scottish example, Scots pine is preferable to Sitka spruce only at the lowest interest rates and if a $\mathrm{CO}_{2}$ fertilisation effect is assumed. Since Scots pine was the best alternative out of some 20 species screened by Mason et al. (2012), commercial foresters in Scotland may be reluctant to turn away from Sitka spruce given that that the 2080 scenario is more than one spruce rotation away from the present time. The development of higher value markets for Scots pine timber (Macdonald et al. 2008) might make this species more attractive to growers, as might the provision of a subsidy for planting the less productive species which would increase the rate of return. However, in the absence of such measures, managers' initial approach may be to explore silvicultural options for sites where soil moisture may be limiting such as planting at lower densities or thinning regimes that reduce leaf area and hence water requirements (Pinkard et al. 2010). The former is unlikely to be practical in Sitka spruce because of poorer timber properties in trees planted at densities less than 2,500 stems ha ${ }^{-1}$ (Macdonald and Hubert 2002). However, the latter could be achieved by planting spruce in a self-thinning mixture with pine which gradually develops into a wider spaced stand of spruce without loss of timber quality. Continuous cover forestry has also been proposed as a means of adapting Scottish forests to projected climate change (Ray 2008), but difficulties of modelling the transformation plus uncertainties over the timber outturn (Macdonald et al. 2010) mean that this option was not considered in our analysis.

Our findings are similar to those from other studies in a range of regions (Allen et al. 2010; Bolte et al. 2009; Coops and Waring 2010; Watt et al. 2008) in predicting increased risks from a changing climate for the future role of tree species currently of major importance for timber production. However, while a frequent policy response to such predictions is to encourage species diversification as a means of spreading and reducing the risks (Kolstrom et al. 2011), implementing such a strategy may be problematic in plantation forests with disparate owners, especially if this involves potential financial penalties. For example, diversification away from an existing plantation species can involve 'market' risks if the bulk supply of timber from a known species is partially diluted by the provision of unfamiliar timbers. Previous attempts to deploy alternative species to radiata pine as an active diversification strategy in New Zealand largely failed, partly because of disease affecting the alternatives that were trialled and partly because of their lower productivity (Burdon 2001). Based on this experience, Burdon (op cit.) proposed a revised approach to reducing risks by identifying and planting a small number of contingency species which could be used if radiata pine was at serious risk. However, the main effort would be placed on selecting 'breeds' or genotypes of radiata pine or other major plantation species (e.g. Sitka spruce) that could confer increased resistance against particular pathogens (e.g. Dothistroma) or be less susceptible to the impacts of drought (Ivkovic et al. 2010). The potential impacts of genetic improvement were not considered in our analysis, but these could influence the financial outturns reported here since in Scotland the gains available from tree breeding are higher for Sitka spruce than for Scots pine (Lee 2004).

\section{Conclusion}

The high productivity and acceptable financial returns obtained from the main plantation species used in New Zealand and Scotland can act as a disincentive against species diversification, particularly if the latter are less productive or are perceived to involve some element of market risk. This disincentive is greater because of the comparatively short time 
horizon of operational forestry decisions compared to the long-term impacts of climate change. However, the inevitable occurrence of extreme events not allowed for in our analysis suggests that it will be both prudent and important for measures to be taken that will help safeguard plantation resources and timber supplies in an uncertain future. Generalising the Burdon approach would suggest that the task of identifying contingency species and resistant breeds for an extensive forest plantation resource should be undertaken at an industry-wide level, possibly through a tree breeding cooperative or similar initiative. However, silvicultural strategies for adapting particular forests to projected climate change need to be trialled at a local or regional level, reflecting the variety of forest sites and the range of forest owners and their often very different objectives. By combining an industry-wide knowledge base with the experience gained from local trials, it should be possible to adapt a plantation resource to climate change while sustaining its productivity and financial viability.

Acknowledgments We acknowledge funding from the EU IRSES project Tranzfor for funding travel costs to support this collaboration. Work at Craik Forest was also supported by the EU Interreg 4C project 'ForestClim'. Climate data and future projections for Craik were sourced by Phil Taylor, while John Fonweban provided information from permanent sample plots in Scotland. Special thanks to Future Forests Research Limited (N.Z.) for access to data for Ashley Forest. The collation of the relevant New Zealand permanent sample data was provided by Carolyn Andersen and Christine Dodunski. Climate data and future projections for Ashley were supplied by National Institute of Water and Atmospheric Research and formatted for 3-PG by Duncan Harrison. We are grateful to the journal editors and an anonymous reviewer for helpful comments and suggestions which have improved this manuscript.

\section{References}

Abrams MD (2011) Adaptations of forest ecosystems to air pollution and climate change. Tree Physiol 31:258-261

Ainsworth EA, Long SP (2005) What have we learned from 15 years of free-air $\mathrm{CO} 2$ enrichment (FACE)? A meta-analytic review of the responses of photosynthesis, canopy properties and plan production to rising CO2. New Phytol 165:351-372

Allen CD, Macalady AK, Chenchouini H, Bachelet AD, McDowell N, Vennetier M, Kitzberger T, Rigling A, Breshears DD, Hogg EH, Gonzalez P, Fensham R, Zhang Z, Castro J, Demidova N, Lim J-H, Allard G, Running SW, Semerci A, Cobb N (2010) A global overview of drought and heat-induced tree mortality reveals emerging climate change risks for forests. For Ecol Manag 259:660-684

Almeida AC, Sands PJ, Bruce J, Siggins AW, Leriche A, Battaglia M, Batista TR (2009) Use of a spatial process-based model to quantify forest plantation productivity and water use efficiency under climate change scenarios. Presentation 18th World IMACS/ MODSIM Congress, Cairns, Australia 13-17 July 2009

Almeida AC, Siggins A, Batista T, Beadle C, Fonseca S, Loos R (2010) Mapping the effect of spatial and temporal variation in climate and soils on Eucalyptus plantation production with 3-PG, a process-based growth model. For Ecol Manag 259:1730-1740
Anonymous (2010) A guide for increasing tree species diversity in Wales. Forestry Commission Wales, Aberystwyth: 41

Battaglia M, Bruce J, Brack C, Baker T (2009) Climate change and Australia's plantation estate: analysis of vulnerability and preliminary investigation of adaption options. Forest and Wood Products Australia Limited, Victoria, p 124

Battistiti A, Stasny M, Netherer S, Robinet C, Shopf A, Roques A, Larsson S (2005) Expansion of geographic range in the pine processionary moth caused by increased winter temperatures. Ecol Appl 15:2084-2096

Bolte A, Ammer C, Lof M, Madsen P, Nabuurs G-J, Schall P, Spathelf P, Rock J (2009) Adaptive forest management in central Europe: climate change impacts, strategies and integrative concept. Scand J For Res 24:473-482

Booth TH (2012) Eucalypt plantations and climate change. For Ecol Manag. doi:10.1016/j.foreco.2012.04.004

Brown A, Webber J (2008) Red band needle blight of conifers in Britain. Forestry Commission Research Note 2, Forestry Commission, Edinburgh

Burdon RD (2001) Genetic aspects of risk - species diversification, genetic management and genetic engineering. NZ J For Sci 45:20-25

Clark A (2012) Chapter 2. Climate. The changing climatic environment for New Zealand's land-based sectors. In: Clark A, Nottage R (eds) Impacts of climate change on land-based sectors and adaption options. Prepared for the Ministry for Primary Industries by National Institute of Water and Atmospheric Research Ltd, Wellington, pp 33-82

Coops NC, Waring RH (2010) A process-based approach to estimate lodgepole pine (Pinus contorta Dougl.) distribution in the Pacific Northwest under climate change. Clim Chang 105:313-328

Coops NC, Waring R (2011) Estimating the vulnerability of fifteen tree species under changing climate in Northwest North America. Ecol Model 222:2119-2129

Davis-Colley R, Nicholas I (2008) Chapter 2 - Timber properties and marking history. In: Nicholas I (ed) Best practice with farm forestry timber species. No. 2: Eucalypts. New Zealand Farm Forestry Association Electronic Handbook Series, Wellington, pp. 17-29

Dick MA (1998) Pine pitch canker - the threat to New Zealand. NZ J For Sci 42:30-34

Dunningham A, Kirschbaum M, Payn T, Meason D (2012) Chapter 7. Forestry. Long-term adaption of productive forests in a changing climatic environment. In: Clark A, Nottage R (eds) Impacts of climate change on land-based sectors and adaption options. Prepared for the Ministry for Primary Industries by National Institute of Water and Atmospheric Research Ltd, Wellington, pp 293-346

Edwards PN, Christie JM (1981) Yield models for forest management. Forestry Commission Booklet 48, HMSO, London

Esprey LJ, Sands PJ, Smith CW (2004) Understanding 3-PG using a sensitivity analysis. For Ecol Manag 193:235-250

Forestry Commission (2012) Standing timber volume for coniferous forest trees in Britain. National Forest Inventory report, Forestry Commission, Edinburgh. 20pp. http://www.forestry.gov.uk/pdf/ fcnfi111.pdf/\$FILE/fcnfi111.pdf. Accessed 27 Sept 2012

Ganley RJ, Watt MS, Manning L, Iturritxa E (2009) A global climatic risk assessment of pitch canker disease. Can J For Res 39:22462256

Gardiner BA, Blennow K, Carnus J-M, Fleischer P, Ingermarson F, Landmann G, Lindner M, Marzano M, Nicoll B, Orazio C. Peyron JL, Reviron MP,Schelhaas MJ, Schuck A, Spielmann M, Usbeck T. (2010) Destructive storms in European forests: past and forthcoming impacts. Final report to European Commission-DG Environment. EFI Atlantic, Bordeaux: 138

Gonthier P, Giordano L, Nicolotti G (2010) Further observations on sudden dieback of Scots pine in the European Alps. For Chron $86: 110-117$ 
Green S, Hendry SJ, Redfern DB (2008) Drought damage to pole-stage Sitka spruce and other conifers in north-east Scotland. Scott For 62:10-18

Hay AE, Nicholas ID, Shelbourne, CJA (2005) Plantation forestry species: alternatives to radiata pine. In: Colley M (ed) NZIF Forestry handbook New Zealand Institute of Forestry, Wellington, pp. 8386

Hildebrandt P, Knoke T (2010) Investment decisions under uncertainty - a methodological review on forest science studies. For Policy Econ. doi:10.1016/j.forpol.2010.09.001

Hoogstra MA, Heiner S (2009) Future orientation and planning in forestry: a comparison of forest managers' planning horizons in Germany and the Netherlands. Eur J For Res 128:1-11

Intergovernmental Panel on Climate Change (IPCC) (2007) Climate Change 2007: the physical science basis. Summary for policymakers. Contribution of Working Group I to the Fourth Assessment Report of the Intergovernmental Panel on Climate Change. Geneva: WMO

Ivkovic M, Gapare WJ, Wharton T, Jovanovic T, Elm S, McRae TA, Wu HX (2010) Risks affecting breeding objectives for radiata pine in Australia. Aust For 73:265-278

Jarvis PG, Clement RJ, Grace J, Smith KA (2009) The role of forests in the capture and exchange of energy and greenhouse gases. In: Combating climate change - a role for UK forests: main report. The Stationery Office, London. pp. 21-47

Jones TG, McConnochie RM, Shelbourne T, Low CB (2010) Sawing and grade recovery of 25-year-old Eucalyptus fastigata, E. globoidea, E. muelleriana and E. pilularis. NZ J For Sci 40:19-

Karnosky DF (2003) Impacts of elevated atmospheric $\mathrm{CO}_{2}$ on forest trees and forest ecosystems: knowledge gaps. Environ Int 29:161-169

Kennedy F (2002) The Identification of soils for forest management. Forestry Commission Field Guide. Forestry Commission, Edinburgh, p 56

Kolstrom M, Lindner M, Vilen T, Maroschek M, Seidl R, Lexer MJ, Netherer S, Kremer A, Delzon S, Barbati A, Marchetti M, Corona P (2011) Reviewing the science and implementation of climate change adaptation measures in European forestry. Forests 2:961-982

Kurz WA, Dymond CC, Stinson G, Rampley GJ, Neilson ET, Carroll AL, Ebata T, Safranyik L (2008) Mountain pine beetle and forest carbon feedback to climate change. Nature 452:987-990

Landmann G, Dreyer E (eds) (2006) Impacts of drought and heat on forest. Synthesis of available knowledge, with emphasis on the 2003 event in Europe. AnnFor Sci 3: 567-652

Landsberg JJ, Waring RH (1997) A generalised model of forest productivity using simplified concepts of radiation-use efficiency, carbon balance and partitioning. For Ecol Manag 95:209-228

Lawrence A, Gillett S (2011) Human dimensions of adaptive forest management and climate change: a review of international experience. Forestry Commission Research Report, Forestry Commission, Edinburgh: 44

Lee SJ (2004) The products of conifer tree breeding in Britain. Forestry Commission Information Note 58, Forestry Commission, Edinburgh

Lindner M, Maroschek M, Netherer S, Kremer A, Barbati A, GarciaGonzalo J, Seidl R, Delzon S, Corona P, Kolstrom M, Lexer MJ, Marchetti M (2010) Climate change impacts, adaptive capacity, and vulnerability of European forest ecosystems. For Ecol Manag 259:698-709

Macdonald E, Hubert J (2002) A review of the effects of silviculture on timber quality of Sitka spruce. Forestry 75:107-138

Macdonald E, Cooper G, Davies I, Freke B (2008) Scots pine timber: current utilization and future market prospects in Scotland. Scott For 62:12-21

Macdonald E, Gardiner BA, Mason WL (2010) The effects of transformation of even-aged stands to continuous cover forestry on conifer $\log$ quality and wood properties in the UK. Forestry 83:1-16

Magnani FM, Mencuccini M, Borghetti P, Berbigier F, Berninger S, Delzon A, Grelle A, Hari P, Jarvis PG, Kolari P, Kowalski AS,
Lankreijer H, Law BE, Lindroth A, Loustau D, Manca G, Moncrieff JB, Rayment M, Tedeschi V, Valentini R, Grace J (2007) The human footprint in the carbon cycle of temperate and boreal forests. Nature 447:848-852

Manley B (2012) Discount rates used for forest valuation - results of the 2011 survey. NZ J For Sci 56:21-28

Mason WL, Meredieu C (2011) Silvicultural strategies, sustainability, and adaptation to climate change in forests of the Atlantic region of Europe. Journal of Forest Planning 16:1-11

Mason WL, Petr M, Bathgate S (2012) Silvicultural theories for adapting planted forests to climate change: from theory to practice. J For Sci 58:265-277

Meason, DF, Almeida, A, Manning, L, Nicholas, I (2011) Preliminary parameterisation of the hybrid model 3-PG for Eucalyptus fastigata in New Zealand. Unpublished report. New Zealand Forest Research Institute Limited, Rotorua

Ministerial Conference on the Protection of Forests in Europe (MCPFE) (2007) State of Europe's forests 2007. MCPFE Liaison unit, Warsaw, Poland, p. 247

Ministry of Agriculture and Forestry (MAF) (2011) National Exotic Forest Description 2011. Ministry of Agriculture and Forestry, Wellington

Minnuno F, Xenakis G, Perks MP, Mencuccini M (2010) Calibration and validation of a simple process-based model for the prediction of the carbon balance of Sitka spruce (Picea sitchensis) plantations. Can J For Res 40:2411-2426

Murphy J, Sexton D, Jenkins G, Boorman P, Booth B, et al. (2009) UK Climate Projections science report: Climate change projections. Available at: http://ukclimateprojections.defra.gov.uk/content/view/ 944/500/. Accessed 23 Sept 2012

Newsome PFJ, Wilde RH, Willoughby EJ (2008) Land resource information system spatial data layers. Data dictionary. Landcare Research New Zealand, Palmerston North

Nicholas I, Watt MS (2011) The three potentially most useful exotic forest species for south eastern North Island marginal hill country. NZ J For Sci 56:15-19

Nicoll BC, Gardiner BA, Rayner B, Peace AJ (2006) Anchorage of coniferous species in relation to species, soil type, and rooting depth. Can J For Res 36:1871-1883

Norby RJ, Warren JM, Iversen CM, Medlyn BE, McMurtrie RE (2010) $\mathrm{CO}_{2}$ enhancement of forest productivity constrained by limited nitrogen availability. Proc Natl Acad Sci USA 107:19368-19373

Pinkard L, Battaglia M, Howden M, Bruce J, Potter K (2010) Adaptation to climate change in Australia's plantation industry. CSIRO, Hobart, $\mathrm{p} 78$

Pussinen A, Nabuurs GJ, Wieggers HJJ, Reinds GJ, Wamelink GWW, Kros J, Mol-Dijkstra JP, De Vries W (2009) Modelling long-term impacts of environmental change on mid- and high latitude European forests and options for adaptive forest management. For Ecol Manag 258:1806-1813

Ray D (2008) Impacts of climate change on forests in Scotland. A preliminary synopsis of spatial modelling research. Forestry Commission Research Note 101, Forestry Commission, Edinburgh

Richards EG (2003) British forestry in the twentieth century, policy and achievements. Koninklijke Brill, Leiden

Sands PG (2010) 3PG PJS user manual. Taroona, p. 27

Schelhaas MJ, Nabuurs GJ, Schuck A (2003) Natural disturbances in the European forests in the 19th and 20th centuries. Glob Chang Biol 9:1620-1633

Scinocca JF, McFarlane NA, Lazare M, Li J, Plummer D (2008) The $\mathrm{CCCma}$ third generation AGCM and its extension into the middle atmosphere. Atmos Chem Phys 8:7055-7074

Seidl R, Lexer MJ, Jäger D, Hönninger K (2005) Evaluating the accuracy and generality of a hybrid patch model. Tree Physiol 25:939-951

Song X, Bryan BA, Paul KI, Zhao G (2012) Variance-based sensitivity analysis of a forest growth model. Ecol Model 247:135-143 
Spittlehouse DL, Stewart RB (2003) Adaptation to climate change in forest management. BC Journal of Ecosystems and Management 4:1-11

Stone C, Penman T, Turner R (2011) Managing drought-induced mortality in Pinus radiata plantations under climate change conditions: a local approach using digital camera data. For Ecol Manag 265:94-101

Straw N, Fielding N, Green G, Price J, Williams D (2011) Defoliation and growth relationships for mid-rotation Sitka spruce attacked by the green spruce aphid, Elatobium abietinum (Walker). For Ecol Manag 262:1223-1235

Waring RH, McDowell N (2002) Use of a physiological process model with forestry yield tables to set limits on annual carbon balances. Tree Physiol 22:179-188

Watt MS, Kirschbaum MUF, Paul TSH, Tait A, Pearce HG, Brockerhoff EG, Moore JR, Bulman LS, Kriticos DJ (2008) The effect of climate change on New Zealand's planted forests: impacts, risks and opportunities. http://www.mpi.govt.nz/newsresources/publications Accessed 27 Sept 2012

Watt MS, Kriticos DJ, Alcaraz S, Brown AV, Leriche A (2009) The hosts and potential geographic range of Dothistroma needle blight. For Ecol Manag 257:1505-1519
Watt MS, Ganley RJ, Kriticos DJ, Manning LK, Brockerhoff EG (2011) The threat to new Zealand's plantation forests from four pests under a changing climate. MAF Technical Paper 2011/4. Ministry of Agriculture and Forestry, Wellington, New Zealand. 9 $\mathrm{pp}$

Webb TH, Wilson AD (1995) A manual of land characteristics for evaluation of rural land. Landcare research science series No. 10. Landcare Research New Zealand, Lincoln

Weiskittel A, Crookston NL, Radtke PJ (2011) Linking climate, gross primary productivity, and site index across forests of the western United States. Can J For Res 41:1710-1721

Woods A, Coates KD, Hamann A (2005) Is an unprecedented Dothistroma needle blight epidemic related to climate change? BioScience 55:761-769

Xenakis G, Ray D, Mencuccini M (2008) Sensitivity and uncertainty analysis from a coupled 3-PG and soil organic matter decomposition model. Ecol Model 219:1-16

Yousefpour R, Jacobsen JB, Thorsen BJ, Meilby H, Hanewinkel M, Oehler K (2012) A review of decision-making approaches to handle uncertainty and risk in adaptive forest management under climate change. Ann For Sci 69:1-15 